\title{
PASSERSBY: THE POLITICS AND POETICS OF AFROPOLITANISM
}

\author{
Katarzyna WIĘCKOWSKA (Nicolaus Copernicus University in Toruń) \\ ORCID: 0000000334083695
}

In "Bye-Bye, Babar (Or: What is an Afropolitan?)," an essay published in the LIP Magazine in 2005, Taiye Selasi used the term "Afropolitan" to describe "the newest generation of African emigrants" who "belong to no single geography, but feel at home in many" and who "forge a sense of self from wildly disparate sources." A combination of "African" and "cosmopolitan," Afropolitanism, as intended by Selasi, captures the generational experience of affluent youth, "coming soon or collected already at a law firm/chem lab/jazz lounge near you," whose characteristic features include a "funny blend of London fashion, New York jargon, African ethics, and academic successes." Afropolitans, as Selasi writes, are "ethnic mixes" or "cultural mutts," usually multilingual, and in constant movement, connected to "at least one place on The African Continent" as well as to "the G8 city or two (or three)," thus forming and sustaining cultural rather than geographical identifications. ${ }^{3}$ In contrast to their parents, who left Africa in the 1960s and 1970s and "sought safety in traditional professions like doctoring, lawyering, banking, engineering," they enter "into fields like media, politics, music, venture capital, design." Most importantly, no longer defined by their skin colour, place of birth, or nationality, Afropolitans are, as Selasi declares, "not citizens, but Africans of the world."

Selasi's widely read and discussed article on Afropolitanism marks the shift in thinking about Africa and what it means to be African, described as "the cosmopolitan turn" that began in the 2000s and entailed a movement away from race-based epistemologies and cultural homogeneity in favour of a sense of heterogeneous cultural

${ }^{1}$ Taiye Selasi, "Bye-bye Babar (Or: What is an Afropolitan?)," LIP Magazine, March 3, 2005, http://thelip.robertsharp.co.uk/?p=76.

${ }_{2}^{2}$ Ibid.
${ }^{3}$ Ibid.
${ }^{4}$ Ibid.
${ }^{5}$ Ibid. 
heritage and hybrid identities. ${ }^{6}$ Afropolitanism presents a break with Pan-Africanism and Afrocentrism ${ }^{7}$ and a reaction against Afro-pessimism, described by Simon Gikandi as an attitude to Africa that emerged in the 1980s and 1990s and that saw "the continent and its populace [as] hopelessly imprisoned in its past, trapped in a vicious cycle of underdevelopment, and held hostage to corrupt institutions." In contrast, Afropolitanism aims to re-conceptualize Africa as a source of valuable and varied cultural traditions, and to re-define Africans as cultural nomads. In effect, it offers a model of individual and collective identity that captures the sense of mobility and displacement experienced in a globalized world and presents a counter-narrative to the increasingly separatist, populist, and violent responses to migrants and migrations. In this article, I discuss the notion of Afropolitanism as presented by Selasi in various articles and in her Ghana Must Go (2013), "an Afropolitan novel" and an example of Afropolitan literary aesthetics. I present an overview of the major ways in which the concept has been developed and contested and briefly discuss its usage in popular culture and art projects. ${ }^{9}$ Throughout the article, I argue, following Donald Morales, that although Afropolitanism does not provide "an all-inclusive theory of modern African writing," it nonetheless functions as a useful term for designating the experience of a group of writers variously linked to Africa and opens up the space for new narratives of the continent and its people. ${ }^{10}$ I conclude by referring to the moral implications of Afropolitanism, outlining some affinities between the concept and the ethics of passerby developed by Achille Mbembe.

The manifest aim of Selasi's 2005 article on Afropolitanism was to find a way of describing an experience specific to people who, like herself, were well-educated and well-to-do and who formed a complex relation to Africa and to the various places in which they grew up; as she writes, "'Home' for this lot is many things: where their parents are from; where they go for vacation; where they went to school; where they see old friends; where they live (or live this year)." ${ }^{, 11}$ While she insisted that for people like her, "being African must mean something," she also explicitly refused to identify with the prevalent images of Africa and Africans, starting from Akeem the African prince and

\footnotetext{
${ }^{6}$ Sarah Balakrishnan, "The Afropolitan Idea: New Perspectives on Cosmopolitanism in African Studies," History Compass 15, no. 2 (February 2017): 2-6, https://doi.org/10.1111/hic3.12362.

${ }^{7}$ Ibid, 2.

${ }^{8}$ Simon Gikandi, "Foreword: On Afropolitanism," in Negotiating Afropolitanism: Essays on Borders and Spaces in Contemporary African Literature and Folklore, ed. Jennifer Wawrzinek and J.K.S. Makokha (Amsterdam and New York: Rodopi, 2011), 9.

${ }^{9}$ Taking into account the immense popularity of the concept and the ongoing critical debate, I focus only on the best known representatives and major lines of argument.

10 Donald Morales, “An Afropolitan 2017 Update," Journal of the African Literature Association 11, no. 2 (2017): 226, https://doi.org/10.1080/21674736.2017.1375659. Morales convincingly argues that Selasi's goal in coining the term was merely to "define a group of writers who reside in various capitals and whose works give a broader sense of who and what an African writer is" ("An Afropolitan," 233).

${ }_{11}$ Selasi, "Bye-Bye, Babar," 2005. Selasi herself is one of the best examples of an Afropolitan with a complex and complicated relation to home. She was born in 1979 in London to parents from Nigeria and Ghana and was raised in Boston, Massachusetts. She is a graduate of Yale and Oxford and she has lived in Delhi, New York, Rome, Berlin, and Lisbon. Writer, photographer, and producer, she has participated in various projects, including building the openair library the Gwangju River Reading Room (with David Adjaye), co-producing Afripedia, a documentary series about urban African creatives (with Teddy Goitom) and providing text for the documentary Exodus. Where I Come from Is Disappearing (2017).
} 
Babar the elephant from Eddie Murphy's Coming to America (1988) and finishing with the global media portrayal of the continent through war, hunger, and corruption. Thus, in this formulation, Afropolitanism relates to both the public and private sphere, as an attempt to construct a different sense of personal identity and to re-shape the obsolete and simplifying images of the land and the people in contemporary media culture. ${ }^{12}$ Importantly, Selasi describes "a willingness to complicate Africa," that is, "to engage with, critique, and celebrate the parts of Africa that mean most to them," as the distinguishing feature of Afropolitans, who are responsible for finding a meaning of "African culture" that moves "beyond pepper soup and filial piety." complicate established notions relates also to identity, which "the Afropolitan must form [...] along at least three dimensions: national, racial, cultural, ${ }^{, 14}$ none of which can be taken for granted. Ultimately, the concept of Afropolitanism effectively questions the notions of stable identity, whether national, cultural, or racial and stresses the cultural complexity of Africa as an identificatory site, pointing to the need "to understand what is ailing in Africa alongside the desire to honor what is wonderful, unique." ${ }^{\prime 15}$ Accordingly, becoming Afropolitan does not entail romanticizing the past or erasing painful experiences, but assumes a confrontation and coming to terms with the entirety of the history of the African continent.

Since the publication of her essay in 2005, Selasi has discussed Afropolitanism in several texts focusing, among other things, on nationality and its importance for cultural production, in particular literature. The title of her TED talk from 2014, "Don't Ask Where I'm From, Ask Where I'm a Local," clearly expresses her belief that countries no longer provide sufficient basis for understanding human beings and that "the language of nationality" should be replaced with "the language of locality" to focus on those spaces where "real" life occurs. As Selasi argues, nationality should give way to locality since it is a set of experiences — of rituals, relationships, and restrictions - that forms a person's identity and not the fact of belonging to a particular nation. Like in "Bye-Bye, Babar," in the speech she places cultural identity over national origins, but this does not mean that she denies the importance of nations: as she states, "Culture exists in community, and community exists in context. Geography, tradition, collective memory: these things are important. What I'm questioning is primacy." 16 Accordingly, she describes nationality as one of the restrictions that determine how locality is experienced and calls for putting an end to the "myth of national identity and the vocabulary of coming from [which] confuses us into placing ourselves into mutually exclusive categories" and which denies the fact that "all of us are multi - multi-local, multi-layered." " Selasi describes such denial of multi-locality and variety of human experience as detrimental for literature and for writers, who are expected to follow classifications based on national and ethnic belonging. In the speech opening the International Literature Festival in Berlin in 2013,

12 In "Bye-Bye, Babar," Selasi emphasizes the importance of cultural production by referring to such artists as Keziah Jones, Claude Gruzintsky, David Adjaye, and Chimamanda Achidie as examples of Afropolitans.

${ }^{13}$ Selasi, "Bye-Bye, Babar," 2005.

${ }^{14}$ Ibid.

${ }^{15}$ Ibid.

16 Taiye Selasi, "Don't Ask Where I'm from, Ask Where I'm a Local," October 2014, https://www.ted.com/talks/taiye_selasi_don_t_ask_where_i_m_from_ask_where_i_m_a_local?la nguage $=$ en.

${ }^{17}$ Ibid. 
tellingly titled "African Literature Doesn't Exist,"18 she explicitly addressed the problem of a limited number of subjects and writing styles considered appropriate for an African writer and argued that "to call [her] an African novelist is first to invent some monolithic Africa and second to restrict [her] — [her] characters, their colorfrom overstepping its bounds." ${ }^{19}$ Similarly, in "Stop Pigeonholing African Writers," she asks why writers from Africa must "always bear the burden of representing their continent," claims that they should not be treated as anthropologists or native informants, and wonders whether it may be possible to think of African novelists simply as artists and storytellers who write "for love: love of craft, love of subject." 20 Thus, in the context of literature and art, Afropolitanism may function as an intervention into the accepted modes of writing and may complicate what Africa or African writing means for writers and readers alike.

Ghana Must Go (2013), Selasi's only novel so far, evades stereotypical African subjects by centering on questions of identity rather than on political or social problems of contemporary Africa and complicates the meaning of the continent by focusing on young Afropolitans and their confrontation with the land and its heritage. ${ }^{21}$ The book presents in a non-linear fashion the story of the Sai family: from the arrival of Kweku and Fola to the United States from Ghana and Nigeria respectively to their children's voyage to Kokrobité in Ghana at the end of the novel. Olu, Taiwo, Kehinde, and Sadie, the children, can be considered Afropolitans: Olu is a successful doctor, Kehinde is a famous artist, and Taiwo and Sadie are distinguished by academic successes. Beginning with Kweku's death and ending with his funeral, the novel is divided into three parts titled "Gone," "Going," and "Go." The first part records the moment of Kweku's death in Ghana and his memories, through which the story of his arrival to the United States is presented and the members of his family are described. The second part focuses on Fola and the children as they learn about Kweku's death and offers insights into their lives and problems, and the last section describes Kweku's funeral in his home village. The pivotal event in the novel is Kweku's escape from America and his family after he is unjustly dismissed from his job, which leaves his eldest son, Olu, traumatized and forces Fola to send the twins, Kehinde and Taiwo, to her half-brother in Lagos. At the end of the book, the full impact of Kweku's departure is revealed when Taiwo makes a confession to her mother about the terrible way in which she and

${ }^{18}$ The title of Selasi's talk references Salman Rushdie's seminal essay “Commonwealth Literature Doesn't Exist” (1984).

19 Taiye Selasi, “African Literature Doesn't Exist,” Brittle Paper: An African Literary Experience, November 25, 2013, https://brittlepaper.com/2013/11/selasi-african-literatureliterary-utopia/. It might be useful to evoke at this point Kenneth Binyavanga Wainaina's "How to Write About Africa" (2005), which ridicules expectations forced on African writers, who should, for example, "treat Africa as if it were one country" and "the Land of Wide Empty Spaces," describe "rotting naked dead bodies," and "show how Africans have music and rhythm deep in their souls, and eat things no other humans eat" ("How to Write About Africa," Granta, May 2, 2019, https://granta.com/how-to-write-about-africa/).

${ }_{20}$ Taiye Selasi, "Stop Pigeonholing African Writers," Guardian, July 4, 2015, http://www.theguardian.com/books/2015/jul/04/taiye-selasi-stop-pigeonholing-african-writers. The image of Afropolitan writer is similar to Nicolas Bourriaud's description of altermodern artists as "homo viators," defined by the experience of mobility, travel, and transpassing (Nicolas Bourriaud, "Altermodern Explained: Manifesto," Tate, 2009, https:/www.tate.org.uk/whatson/tate-britain/exhibition/altermodern/altermodern-explain-altermodern/altermodern-explained).

${ }^{21}$ Morales claims that "the freedom to break away from stereotypical themes, places, and characters" is "one of the tenets of Afropolitanism" ("An Afropolitan," 227). 
Kehinde were treated by their depraved uncle and when Olu reveals to his wife his fears of becoming like his father, thus continuing the paternal tradition of departure and betrayal. In the final part of the novel, the family's wounds are revealed if not healed as Sadie, encouraged by her African cousin, discovers her dancing talent, Olu opens to his wife, Taiwo and Kehinde gradually regain the closeness they lost in Lagos, and Fola welcomes Kweku's ghost, thanking him for bringing their children home.

Ghana Must Go opens with a drawing of a family tree, thereby stressing the role of the family in identity formation and pointing to the novel's focus on a sense of belonging and search for home. At the same time, the Sai family are presented as "unfinished, in rehearsal, a production in progress," 22 described by the youngest daughter Sadie as "without gravity, completely unbound," with "no roots spreading out underneath them, with no living grandparent, no history."23 A similar feeling of deprivation is suffered by Olu who surveys his friends' family portraits "aching with longing, for lineage, for a sense of having descended from faces in frames." 24 A sense of belonging is reached at the end of the novel through their encounter with Africa thanks to which they recreate their lineages, becoming part of a forgotten family history of dancers, builders, artists, and dreamers. This sense of belonging, however, is undermined by the title of the final part, "Go," which suggests a beginning of a journey rather than its end, thereby negating the possibility of constructing a stable identity based on a myth of fixed origins. The titles of the parts — "Gone," "Going," "Go" create an atmosphere of movement and travel ${ }^{25}$ that is reinforced by the title of the novel: Ghana Must Go refers to the executive order of the President of Nigeria in 1983 which led to massive migration and effective expulsion of Ghanaians from the country, and it also recalls the "Ghana Must Go bag," known as the "migrant bag," through which the event has been recorded in popular culture. Thus, the book emphasizes migration and movement, refusing to present Ghana as "an ancestral place of origins" that comfortingly offers "secure roots and spontaneous bonding." ${ }^{26}$ Instead, Ghana is portrayed as a space for grief, family reconciliation, and reattachment, which takes the Sais back to the past to let them go into the future. ${ }^{27}$

Ghana Must Go opens with an image of Kweku dying "barefoot on a Sunday before sunrise, his slippers by the doorway to the bedroom like dogs, ${ }^{28}$ and finishes with the same slippers handed over to Fola in a Ghana Must Go bag. Thus, rather than a sign of the stability and security commonly associated with home, the father's "migrating slippers" become a legacy of displacement and movement and a symbol of an "unsettled sense of belonging" which Eva Rask Knudsen and Ulla Rahbek describe as a characteristic feature of the Afropolitan literary aesthetics. ${ }^{29}$ According to Knudsen and Rahbek, such aesthetics contains "the trope of a mobility-induced anxiety about place and about self" resulting from the state of being "in transit" and "multi-local" that forms the

${ }^{22}$ Taiye Selasi, Ghana Must Go (New York: Penguin, 2013), 123.

${ }^{23} \mathrm{Ibid}, 146$.

${ }^{24}$ Ibid, 251.

25 Maximilian Feldner, Narrating the New African Diaspora: 21st Century Nigerian Literature in Context (Cham: Palgrave Macmillan, 2019), 134.

${ }^{26}$ Eva Rask Knudsen and Ulla Rahbek, "An Afropolitan Literary Aesthetics? Afropolitan Style and Tropes in Recent Diasporic African Fiction," European Journal of English Studies 21, no. 2 (August 2017): 123, https://doi.org/10.1080/13825577.2017.1344473.

${ }^{27}$ Ibid, 124.

${ }^{28}$ Selasi, Ghana, 3.

${ }^{29}$ Knudsen and Rahbek, "Afropolitan Literary Aesthetics," 123. 
experience of a contemporary transnational subject. ${ }^{30}$ In Selasi's novel, the "recurring sense of unease about belonging" 31 and about identity that characterizes Afropolitans and Afropolitan literary aesthetics is expressed by the concluding injunction to go, repeated in the book's title, as well as by the practice of naming the children of Kweku and Fola which records the Sais' displaced origins: "first name: Nigerian, middle name: Ghanaian, third name: Savage, last name: Sai." ${ }^{32}$ Accordingly, while Ghana Must Go presents the relation to an African origin or location as a crucial element of identity formation, it also depicts it as unstable and "a matter of continuous and conscious negotiation or of a personal engagement from a position of living elsewhere." 33

The connections between mobility, transnationality, and (African) identity outlined by Selasi have been elaborated on by Achille Mbembe, whose 2007 article titled "Afropolitanism" provides the other major point of origin for the concept. ${ }^{34}$ While Selasi describes the goal of her 2005 essay as "no more and no less" than to provide "a description of a particular experience," a broader scope, defining it as "an aesthetic and a particular poetic of the world," "a way of being in the world," and also as "a political and cultural stance in relation to the nation, to race and to the issue of difference in general." ${ }^{, 36}$ Mbembe points to the political and historical dimensions of the concept by describing it as outlining "a new form of African modernity" which rejects "any form of victim identity" while remaining "aware of the injustice and violence inflicted on the continent and its people by the law of the world." ${ }^{37}$ For Mbembe, Afropolitanism is "transnational," that is, constructed through processes of "cultural mixing," blending, superimposing, and "interweaving of worlds" which may not have been "chosen freely" but which have been domesticated and mastered. ${ }^{38}$ If Selasi links Afropolitanism to an early $21^{\text {st }}$-century experience of migrating from Africa, thus locating it in a particular time and space, Mbembe sees it as a quality specific to the continent which has always been a world in movement and whose cultural history "can hardly be understood outside the paradigm of itinerancy, mobility and displacement." 39 Ultimately, for Mbembe, Afropolitanism is

${ }^{30}$ Ibid, 118 .

${ }^{31}$ Ibid.

${ }^{32}$ Selasi, Ghana, 18

${ }^{33}$ Knudsen and Rahbek, "Afropolitan Literary Aesthetics," 118.

${ }^{34}$ The double origin of the term in Selasi's essay and Mbembe's text is stressed by many critics, including Balakrishnan, who offers the following definition of Afropolitanism: "Coined by Taiye Selasi (2005) and Achille Mbembe (2007), the term refers to an Afro-cosmopolitan ethos of transcending national differences to forge multiracial communities." ("Afropolitanism and the End of Black Nationalism," in Routledge International Handbook of Cosmopolitanism Studies, ed. Gerard Delanty (New York: Routledge, 2019), 575). In another text, Balakrishnan writes that scholars treat Mbembe and Selasi as if they were in conversation, "although this was not likely the case" ("The Afropolitan Idea," 2).

35 Taiye Selasi, "Afropolitanism - No Less and No More," Enkare Review, October 2, 2016, https://enkare.org/2016/10/02/taiye-selasi-afropolitan/.

36 Achille Mbembe, "Afropolitanism," in Africa Remix: Contemporary Art of a Continent, ed. Simon Njami and Lucy Durán (Johannesburg: Jacana Media, 2007), 29.

${ }^{37}$ Ibid, 29. In "Bye-Bye, Babar," Selasi also discusses the political dimension of the concept in terms of a post-racial society: as she writes, "how we conceive of race will accord with where we locate ourselves in the history that produced 'blackness' and the political processes that continue to shape it" ("Bye-Bye, Babar," 2005).

${ }^{38}$ Ibid, 27-29.

${ }^{39}$ Ibid, 27. 
a kind of cultural, historical, and aesthetic sensitivity whose key elements include: "Awareness of the interweaving of the here and there, the presence of the elsewhere in the here and vice versa, the relativisation of primary roots and memberships and the way of embracing, with full knowledge of the fact, strangeness, foreignness and remoteness." 40

Echoing Mbembe's definition of Afropolitanism as "a geography of circulation and mobility," "Simon Gikandi describes it as "a way of being African in the world" that allows one "to embrace and celebrate a state of cultural hybridity - to be of Africa and of other worlds at the same time." $" 42$ Similarly to Mbembe, Gikandi sees in the concept an opportunity to consider the issue of difference in general and to rethink Africa "outside the trope of crisis" and loss, approaching migration as "a new ontology, not a tragic drama of sorrow," or not only as such. ${ }^{43}$ For both scholars, Afropolitanism creates the space for a positive view on hybridity and migration, a perspective adopted also by Chielozona Eze who argues that "Afropolitanism suggests a reading of the African postcolonial identity as necessarily transcultural, transnational, indeed, cosmopolitan." "F4 Following Mbembe's intuition that Afropolitanism involves "the ability to recognise one's face in that of a foreigner," 45 Eze proposes to see Afropolitanism as "a new ethics of being" 46 which requires "transcending local geographies" and moving "beyond the confines of ascribed identities." self and beyond one's interest creates "empathic imagination" which makes it possible to see the world from other people's perspective "without any traces of superiority or a position of power or privilege that could be detected in pity." 48 In effect, as Eze claims, Afropolitanism should be understood as "an individual's effort to contest ascribed identity, and to forge a new, more expansive one by relating to other people., $" 49$

Since its publication in 2005, Selasi's essay on Afropolitanism has been reprinted in numerous venues, making the term extremely popular if contested and leading to the creation of various initiatives (self-)described as Afropolitan as well as to an ongoing academic debate on the critical potential of the concept. A number of writers and novels have been identified and discussed as Afropolitan, including Selasi's Ghana Must Go, Dinaw Mengestu's The Beautiful Things That Heaven Bears (2007), Teju Cole's Open City (2011), Yvonne Owuor's Dust (2014), Sefi Atta's A Bit of Difference (2013), and Chimamanda Ngozi Adichie's Americanah (2013). ${ }^{50}$ The notion of Afropolitanism has

${ }^{40}$ Ibid, 28.

${ }^{41}$ Achille Mbembe and Sarah Balakrishnan, "Pan-African Legacies, Afropolitan Futures: A Conversation with Achille Mbeme," Transition 120, no. 1 (2016): 120, http://www.jstor.org/ stable/10.2979/transition.120.1.04.

${ }^{42}$ Gikandi, "Foreword: On Afropolitanism," 9.

${ }^{43}$ Ibid, 9-10.

${ }^{44}$ Chielozona Eze, "Rethinking African Culture and Identity: The Afropolitan Model," Journal of African Cultural Studies 26, no. 2 (2014): 241, https://doi.org/10.1080/13696815.2014.894474.

${ }^{45}$ Mbembe, "Afropolitanism," 28.

${ }^{46}$ Chielozona Eze, "We, Afropolitans," Journal of African Cultural Studies 28, no. 1 (2016): 116, https://doi.org/10.1080/13696815.2015.1100065.

${ }^{47}$ Eze, "Rethinking African Culture and Identity," 242.

${ }^{48}$ Ibid, 243.

${ }^{49}$ Ibid, 245.

${ }^{50}$ In 2014, Black Entertainment Television published the following list of "Ten Afropolitan Writers You Should Know": Dinaw Mengestu, Chimamanda Ngozi Adichie, Helen Oyeyemi, NoViolet Bulawayo, Teju Cole, Taiye Selasi, Olufemi Terry, Aminatta Forna, Kabelo "Sello" Duiker, and Alain Mabanckou (July 7, 2014, https://www.bet.com/news/global/photos/2014/07/10- 
been explored in numerous art projects, including the show "Flow" in Harlem in 2008 featuring the work of young diaspora artists; an exhibition of South African photography and fashion titled "Friday Late: Afropolitans" in the Victoria and Albert Museum in 2011, followed by a panel on the meaning of Afropolitanism; and an exhibition "Africans in America" (2011) in the Houston Museum of African-American Culture, also followed by a panel on "The New Beat of Afropolitans." In 2013, the Royal African Society organized a literature event called "Fantasy or Reality? Afropolitan Narratives of the Twenty-first Century," and the African Literature Association conference in Bayreuth Germany in 2015 convened three panels dedicated to Afropolitanism. ${ }^{51}$ The concept has been disputed across multiple academic papers and journals as well as two collections of critical essays: Negotiating Afropolitanism, an early study of the notion edited by Jennifer Wawrzinek and J.K.S. Makokha in 2010, and Afropolitanism: Reboot (2017) edited by Carli Coetzee. Interestingly, the province of Gauteng, South Africa and the University of Cape Town have officially declared themselves Afropolitan, building on the sense of Afropolitanism as heralding a multi-racial or post-racial modernity. ${ }^{52}$ Out of the many websites dedicated to the concept, the award-winning blog MsAfropolitan is worth mentioning: it was founded in 2010 by Minna Salami, a Nigerian-Finnish and Swedish writer, who describes its aim as connecting "feminism with critical reflections on contemporary culture from an Africa-centred perspective." ${ }^{33}$ Afropolitanism has enjoyed an enormous commercial success, with multiple products advertised as Afropolitan and for Afropolitans. This is the case of The Afropolitan, a magazine founded in 2006 and addressed to "the African elite," that is, "successful, urban, intelligent, culturally aware and savvy Africans that are considered global citizens of the Word" 54 as well as The Afropolitan Shop, an online boutique that began in 2007 as a blog called The Afropolitan Network and whose aim is "to tell an African Design Story" and to give a global platform to local African designers. ${ }^{55}$ The variety of ways in which Afropolitanism has been engaged with illustrates the critical capaciousness of the concept but also points to its possible misuse, in particular the danger of turning Africa into a sanitized and profit-oriented brand.

Afropolitanism has given rise to ethical thought but it has also been criticized for its elitism and class bias, its a-political stance, and commodification. ${ }^{56}$ Most critics follow Binyanvanga Wainaina's arguments, who famously rejected the concept in his plenary address "I am a Pan-Africanist, not an Afropolitan," delivered at the 2012 African Studies Association UK, claiming that it is merely a product-driven and design-

afropolitan-writers-you-should-know.html). The category of an Afropolitan writer or novel is a contested one; Feldner, for example, claims that "Selasi's novel presents perhaps the only convincing narrativization of Afropolitanism" (Narrating the New African Diaspora, 127).

${ }^{51}$ The list of art projects and academic panels is based on Eze, "Rethinking African Culture and Identity," 239; Morales, "An Afropolitan," 225; and Balakrishnan, "Afropolitanism and the End of Black Nationalism," 577.

52 Balakrishnan, "Afropolitanism and the End of Black Nationalism," 577; see also: Karen MacGregor, "Top-ranked university goes 'Afropolitan'," University World News, November 25, 2012, https://www.universityworldnews.com/post.php?story=20121124180508500.

53 "Bio," MsAfropolitan, http://www.msafropolitan.com/.

54 "Contact Media and Communications," Afropolitan Magazine, https://www.contactmedia. co.za/publishing/afropolitan-pub.

55 “About Us," The Afropolitan Shop, https://theafropolitanshop.com/pages/about-us.

${ }^{56}$ Susanne Gehrmann, "Cosmopolitanism with African Roots: Afropolitanism's Ambivalent Mobilities," Journal of African Cultural Studies 28, no. 1 (November 2015): 2, httt://doi.org/ 10.1080/13696815.2015.1112770. 
focused capitalist stunt. ${ }^{57}$ Another major line of criticism concerns the need to create a special term to denote African cosmopolitans, which has been seen as, on the one hand, placing Africans outside the general history of humanity ${ }^{58}$ and, on the other, "promoting territorialised and potentially racialised biases" by tying the concept exclusively to the African continent. ${ }^{59}$ Perhaps the most pertinent critique concerns the notion's elitism and the difference between imagined Afropolitans and actual Africans; as Sylvester Okwunodu Ogbechie points out, in contrast to the freedom of movement enjoyed by Afropolitans, there is "no immigration policy anywhere in the Western world that welcomes Africans," but there is ample "evidence of major bias against African global mobility." ${ }^{60}$ Ultimately, as Maximilian Feldner warns, "The problem of Afropolitanism is [...] that the emphasis on its members' jetting across the globe can serve to cover over other, less auspicious, forms of African migration, such as the attempts to get into Europe by travelling through the Sahara and by boat across the Mediterranean Sea." ${ }^{\prime 61}$

The concept of Afropolitanism expresses a desire for movement and freedom that runs counter to the reality of the refugee crisis of the early $21^{\text {st }}$ century. Writing about the crisis, Mbembe suggests that the best way to "resist the claim by one province of the world to a universal right of predation, [might be] daring to imagine the impossible - the abolition of borders, that is to say, giving all inhabitants of the Earth $[\ldots]$ the inalienable right to freedom of movement on this planet." ${ }^{32}$ Freedom of movement, Mbembe argues, is vital because "becoming-human-in-the-world" is a matter of movement, journeying, and transfiguration and not of birth, origin, or race.$^{63}$ The desire for unrestrained passage lies at the heart of Afropolitanism, as expressed by the protagonist of Selasi's novel who craves "[t]o be 'free,' [...] to be 'human.' Beyond being 'citizen,' beyond being poor." ${ }^{64}$ At the beginning of the $21^{\text {st }}$ century, the concept of Afropolitanism creates space for movement, sketching the routes that may be taken by African literature, writers, readers, and thinkers. ${ }^{65}$ At the same time, it expresses an unsettled sense of belonging which may give rise to two types of social bodies:

57 Stephanie Bosch Santana, "Exorcizing the Future: Afropolitanism's Spectral Origins," Journal of African Cultural Studies 128, no. 1 (2015): 121, https://doi.org/10.1080/13696815. 2015.1105128. There exists no recording of Wainaina's speech.

${ }^{58}$ Chimamanda Adichie in Bosch Santana, "Exorcizing the Future," 122.

${ }^{59}$ Anna-Leena Toivanen, "Cosmopolitanism's New Clothes? The Limits of the Concept of Afropolitanism," European Journal of English Studies 21, no. 2 (2017): 201, http://doi.org/ 10.1080/13825577.2017.1344475.

60 Sylvester Okwunodu Ogbechie, “"Afropolitanism': Africa without Africans (II)," AACHRONYM, April 4, 2008, http://aachronym.blogspot.fi/2008/04/afropolitanism-more-africawithout.html. Interestingly, Ogbechie comments in the article on the show "Flow" described above.

${ }^{61}$ Feldner, Narrating the New African Diaspora, 130.

${ }^{62}$ Achille Mbembe, Necropolitics, transl. Steven Corcoran (Durham and London: Duke University Press, 2019), 184.

${ }^{63}$ Ibid, 187.

${ }^{64}$ Selasi, Ghana, 91

${ }^{65}$ I build here on Morales's claim that Afropolitanism creates "another space for future thinking and evaluation" of African literature ("An Afropolitan," 226) and Emma Dabiri's sceptical hope that "[p]erhaps the increased presence of the Afropolitan as a literary figure will progressively engender more creative articulations of what Afropolitan can and might mean after all, literature provides the ideal space for such transformative processes to occur" ("Why I am (still) not an Afropolitan," Journal of African Cultural Studies 28, no. 1 (2016): 107, http://doi.org. 10.1080/13696815.2015.1100066). 
communities of passersby, formed by and forming relations "of solidarity and detachment, but never of indifference," wealth, class, or race against a growing list of enemies and strangers. Juxtaposed against "the ordeal of extreme vulnerability" Afropolitanism aptly illustrates the present condition, torn between the (impossible?) dream of the abolition of borders and the reality of the "multiplication of spaces of loss and mourning," and of places turned impassable "for certain classes of populations.",68

\section{BIBLIOGRAPHY}

Balakrishnan, Sarah. "Afropolitanism and the End of Black Nationalism." In Routledge International Handbook of Cosmopolitanism Studies, ed. Gerard Delanty, 575-585. New York: Routledge, 2019.

Balakrishnan, Sarah. "The Afropolitan Idea: New Perspectives on Cosmopolitanism in African Studies." History Compass 15, no. 2 (February 2017): 60-71, https://doi.org/10.1111/hic3.12362.

Bosch Santana, Stephanie. "Exorcizing the Future: Afropolitanism's Spectral Origins.” Journal of African Cultural Studies 128, no. 1 (2015): 120-126, https://doi.org/10.1080/13696815. 2015.1105128.

Bourriaud, Nicolas. “Altermodern Explained: Manifesto.” Tate, 2009. Accessed June 8, 2018, https://www.tate.org.uk/whats-on/tate-britain/exhibition/altermodern/altermodern-explainaltermodern/altermodern-explained.

Dabiri, Emma. "Why I am (still) not an Afropolitan." Journal of African Cultural Studies 28, no. 1 (2016): 104-108, http://doi.org. 10.1080/13696815.2015.1100066.

Eze, Chielozona. "We, Afropolitans." Journal of African Cultural Studies 28, no. 1 (2016): 114 119, https://doi.org/10.1080/13696815.2015.1100065.

Eze, Chielozona. "Rethinking African Culture and Identity: The Afropolitan Model." Journal of African Cultural Studies 26, no. 2 (2014): 234-247, https://doi.org/10.1080/13696815. 2014.894474.

Feldner, Maximilian. Narrating the New African Diaspora: 21st Century Nigerian Literature in Context. Cham: Palgrave Macmillan, 2019.

Gehrmann, Susanne. "Cosmopolitanism with African Roots: Afropolitanism's Ambivalent Mobilities." Journal of African Cultural Studies 28, no. 1 (November 2015): 61-72, httt://doi.org/10.1080/13696815.2015.1112770.

Gikandi, Simon. "Foreword: On Afropolitanism." In Negotiating Afropolitanism: Essays on Borders and Spaces in Contemporary African Literature and Folklore, eds. Jennifer Wawrzinek and J.K.S. Makokha, 9-11. Amsterdam and New York: Rodopi, 2011.

Knudsen, Eva Rask and Ulla Rahbek. "An Afropolitan literary aesthetics? Afropolitan style and tropes in recent diasporic African fiction." European Journal of English Studies 21, no. 2 (August 2017): 115-128, https://doi.org/10.1080/13825577.2017.1344473.

MacGregor, Karen. “Top-ranked university goes 'Afropolitan'." University World News, November 25, 2012, https://www.universityworldnews.com/post.php?story=20121124180508500.

Mbembe, Achille. Necropolitics, transl. Steven Corcoran. Durham and London: Duke University Press, 2019.

Mbembe, Achille and Sarah Balakrishnan. "Pan-African Legacies, Afropolitan Futures: A Conversation with Achille Mbeme." Transition 120, no. 1 (2016): 28-37, http://www.jstor.org/stable/10.2979/transition.120.1.04.

Mbembe, Achille. "Afropolitanism." In Africa Remix: Contemporary Art of a Continent, eds. Simon Njami and Lucy Durán, 26-29. Johannesburg: Jacana Media, 2007.
${ }^{66}$ Ibid, 188.
${ }^{67}$ Ibid, 184.
${ }^{68}$ Ibid, 99. 
Morales, Donald. "An Afropolitan 2017 Update." Journal of the African Literature Association 11, no. 2 (2017): 223-237, https://doi.org/10.1080/21674736.2017.1375659.

MsAfropolitan. "Bio." Accessed April 18, 2018, http://www.msafropolitan.com/.

Okwunodu Ogbechie, Sylvester. "“Afropolitanism': Africa without Africans (II)," AACHRONYM, April 4, 2008, http://aachronym.blogspot.fi/2008/04/afropolitanism-moreafrica-without.html.

Selasi, Taiye. "Afropolitanism - No Less and No More." Enkare Review, October 2, 2016, https://enkare.org/2016/10/02/taiye-selasi-afropolitan/.

Selasi, Taiye. "Stop Pigeonholing African Writers." Guardian, July 4, 2015, http://www.theguardian.com/books/2015/jul/04/taiye-selasi-stop-pigeonholing-africanwriters.

Selasi, Taiye. "Don't Ask Where I'm from, Ask Where I'm a Local." Filmed October 2014 at TEDxBeaconStreet, Brookline, MA. Video, 16:31, https://www.ted.com/talks/taiye_ selasi_don_t_ask_where_i_m_from_ask_where_i_m_a local?language $=e n$.

Selasi, Taiye. "Áfrican Literature Doesn't Exist." Brittle Paper: An African Literary Experience, November 25, 2013, https://brittlepaper.com/2013/11/selasi-african-literature-literary-utopia/.

Selasi, Taiye. Ghana Must Go. New York: Penguin, 2013.

Selasi, Taiye. "Bye-bye Babar." LIP Magazine, March 3, 2005, http://thelip.robertsharp.co.uk/?p=76.

"Ten Afropolitan Writers You Should Know." Posted July 7, 2014. Accessed January 6, 2018, https://www.bet.com/news/global/photos/2014/07/10-afropolitan-writers-you-should-know.html.

The Afropolitan. "Contact Media and Communications." Accessed April 18, 2018, https://www.contactmedia.co.za/publishing/afropolitan-pub.

The Afropolitan Shop. "About Us.” Accessed April 18, 2018, https://theafropolitanshop. com/pages/about-us.

Toivanen, Anna-Leena. "Cosmopolitanism's New Clothes? The Limits of the Concept of Afropolitanism.” European Journal of English Studies 21, no. 2 (2017): 189-205, http://doi.org/10.1080/13825577.2017.1344475.

Wainaina, Binyavanga Kenneth. "How to Write About Africa." Granta 92, May 2, 2019, https://granta.com/how-to-write-about-africa/.

\section{PASSERSBY: THE POLITICS AND POETICS OF AFROPOLITANISM}

In this article, I discuss the notion of Afropolitanism as presented by Taiye Selasi in various articles and in her Ghana Must Go (2013), "an Afropolitan novel" and an example of Afropolitan literary aesthetics. I present an overview of the major ways in which the concept has been developed and contested and briefly discuss its usage in popular culture and art projects. Throughout the article, I argue that Afropolitanism may function as a useful term for designating the experience of a specific group of contemporary writers variously linked with Africa and that it may open up the space for the emergence of new narratives of the continent and its people. I conclude the essay by outlining some affinities between the concept of Afropolitanism and the ethics of passersby elaborated by Achille Mbembe.

KEY WORDS: Afropolitanism, ethics, nationality, Taiye Selasi, Achille Mbembe

\section{PRZECHODNIE: POLITYKA I POETYKA AFROPOLITANIZMU}

Artykuł poświęcony jest dyskusji wokół „afropolitanizmu,” pojęcia zaproponowanego przez Taiye Selasi w 2005 roku do opisania doświadczeń drugiego pokolenia emigrantów z Afryki, zamieszkujących metropolie pierwszego świata. W artykule przedstawiam przegląd najważniejszych pozycji krytycznych zarówno kwestionujących, jak i rozwijających koncepcję afropolitanizmu, a także omawiam specyfikę ,afropolitańskiej estetyki” na przykładzie analizy powieści Selasi Ghana Must Go (2013). Artykuł kończę propozycją odczytania figury Afropolitanina poprzez etykę przechodnia opisaną przez Achille Mbembe.

SŁOWA KLUCZOWE: afropolitanizm, etyka, narodowość, Taiye Selasi, Achille Mbembe 